\begin{tabular}{|c|c|c|}
\hline & Klinikal Sains 7 (2) (2019) & \\
\hline & $\begin{array}{l}\text { JURNAL ANALIS KESEHATAN } \\
\text { KLINIKAL SAINS }\end{array}$ & \\
\hline ABDURRAB & http://jurnal.univrab.ac.id/index.php/klinikal & 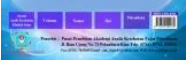 \\
\hline
\end{tabular}

\title{
IDENTIFIKASI KANDUNGAN MERKURI (Hg) PADA URINE PENGGUNA SERUM PEMUTIH WAJAH DENGAN UJI KUALITATIF
}

\author{
Rosa Devitria dan Harni Sepriyani \\ Teknologi Laboratorium Medis, Akademi Analis Kesehatan Yayasan Fajar Pekanbaru \\ Jl. Riau Ujung No. 73 Pekanbaru \\ Telp 082390299978 \\ Email: rosa.devitria@univrab.ac.id
}

\section{Info Artikel}

SejarahArtikel:

Diterima Novemver 2019

Disetujui November 2019

Dipublikasikan Desember

2019

Keywords:

Merkuri,

Serum, Uji Kualitatif

\begin{abstract}
Abstrak
Perawatan kulit dan wajah menjadi hal yang paling utama untuk mendapatkan penampilan yang menarik. Salah satu cara agar wanita tersebut terlihat lebih cantik yaitu menggunakan kosmetik. Selama kosmetik tidak mengandung bahan berbahaya yang secara farmakologis aktif mempengaruhi kulit, penggunaan kosmetik jenis ini menguntungkan dan bermanfaat untuk kulit itu sendiri. Salah satu bahan yang berbahaya yang terdapat di dalam kosmetik yaitu merkuri. Merkuri adalah logam berat yang sangat berbahaya. Tujuan penelitian ini untuk mengetahui ada atau tidaknya merkuri dalam urin pada pengguna serum pemutih wajah.Desain penelitian ini adalah intervensional dengan jenis penelitianbersifat eksperimenyang merupakan suatu percobaan untuk mengetahui adanya kandungan merkuri di dalam sampel dengan menggunakan uji reaksi warna. Dari hasil penelitian yang telah dilakukan tentang identifikasi kandungan merkuri $(\mathrm{Hg})$ pada urine pengguna serum pemutih wajah dengan uji kualitatif terhdap 15 sampel yang diperiksa sampel A positif mengandung merkuri dan sampel B, C, D, E, F, G, H, I, J, K, L, M, N, O negatif yang tidak mengandung merkuri.
\end{abstract}

Kata Kunci: Merkuri, Urine, Serum, Uji Kualitatif

\begin{abstract}
Skin and facial care is the most important thing to get an attractive appearance. One way for these women to look more beautiful is to use cosmetics. As long as cosmetics do not contain pharmaceutically harmful ingredients that affect the skin, this type of cosmetic use is beneficial and beneficial for the skin itself.One of the dangerous ingredients contained in cosmetics, namely mercury. Mercury is a very dangerous heavy metal. The purpose of this study was to determine the presence or absence of mercury in urine in users of face whitening serum. The design of this study is interventional with experimental research which is an experiment to determine the presence of mercury in the sample using the color reaction test. From the results of research that has been carried out on the identification of mercury $(\mathrm{Hg})$ in urine serum users face whitening with a qualitative test of 15 samples examined by sample A positive containing mercury and samples $B, C, D, E, F, G, H, I$, Negative $J, K, L$, $M, N$, $O$ that do not contain mercury.
\end{abstract}

Key Words: Mercury, Urine, Serum, Qualitative Test.

(C) 20xxUniversitasAbdurrab 
Alamatalamatalamat

E-mail: emai@mail.com

\section{PENDAHULUAN}

Kulit merupakan organ terbesar di dalam tubuh, luasnya sekitar $2 \mathrm{~m}^{2}$. Kulit merupakan bagian terluar dari tubuh manusia yang lentur dan lembut. Kulit sangat berguna dan merupakan permukaan luar untuk membatasi lingkungan dalam tubuh dengan lingkungan luar. Kulit juga merupakan salah satu alat inderayaitu indera peraba karena diseluruh permukaan kulit tubuh banyak terdapat syaraf peraba. Dalam tata kecantikan, perawatan kulit dan wajah menjadi hal yang paling utama untuk mendapatkan penampilan yang menarik, keseluruhan badan atau tubuh harus dirawat dengan baik dan dijaga agar selalu bersih, sehat, lembut, segar, dan cantik, terutama bagi kaum wanita yang selalu menginginkan penampilan kulit yang cantik dan sehat ${ }^{[1]}$.

Salah satu cara agar wanita tersebut terlihat lebih cantik yaitu menggunakan kosmetik. Komestik dikenal manusia sejak berabad-abad yang lalu, pada abad ke 19 pemakaian kosmetik mulai mendapat perhatian yaitu selain untuk kecantikan juga untuk kesehatan. Tidak dapat disangkal lagi bahwa produk kosmetik sangat diperlukan oleh manusia. Produk-produk itu dipakai secara berulang setiap haridi seluruh tubuh, mulai dari ujung rambut sampai kaki sehingga diperlukan persyaratan aman untuk dipakai. Untuk mempercantik dan memperbaiki kesehatan kulit diperlukan beberapa kosmetik tertentu, bukan hanya obat. Selama kosmetik tersebut tidak mengandung bahan berbahaya yang secara farmakologis aktif mempengaruhi kulit, penggunaan kosmetik jenis ini menguntungkan dan bermanfaat untuk kulit itu sendiri ${ }^{[2]}$.

Salah satu bahan yang berbahaya yang terdapat di dalam kosmetik yaitu merkuri. Merkuri adalah satu-satunya logam berat yang berbentuk cair pada suhu kamar $\left(25^{\circ} \mathrm{C}\right)$. Dalam sistem periodik, $\mathrm{Hg}$ mempunyai nomor atom 80 . Sebelum diketahui beracun, merkuri telah banyak digunakan oleh manusia untuk kebutuhan hidup, yaitu untuk pengobatan penyakit sifilis pada abad ke-15, sebagai pembersih luka, sebagai komponen merkuri organik untuk diuretia, dan sampai bertahun-tahun digunakan sebagai bahan kosmetik ${ }^{[3]}$.

Kadar merkuri dalam urine dapat dideteksi setelah pemaparan lebih kurang 2-3 minggu. Beberapa hasil studi menunjukkan jika kadar merkuri dalam urine melebihi $100 \mu \mathrm{g} / \mathrm{L}$ akan menyebabkan kerusakan ginjal dan dapat ditemui adanya proteinuria ${ }^{[4]}$. Berdasarkan analisis data yang telah dilakukan pada para pekerja tambang emas tradisional di Desa Panton Luas Kecamatan Sawang Kabupaten Acah rata-rata 2,82 $\mu \mathrm{g} / \mathrm{L}$, sehingga masih dalam batas normal ${ }^{[5]}$.

Hasil penelitian sebelumnya ${ }^{[6]}$ menyebutkan bahwa analisis kandungan merkuri $(\mathrm{Hg})$ pada beberapa krim pemutih wajah tanpa ijin BPOM yang beredar dipasar 45 Manado menunjukkan 1 dari7sampel krim memberikan reaksi positif adanya merkuri dengan menggunakan 
Spektrofotometri Serapan Atom (SSA). Sedangkan hasil penelitian ${ }^{[7]}$, menyebutkan bahwa Identifikasi penetapan kadar merkuri $(\mathrm{Hg})$ dalam krim pemutih kosmetika herbal menggunakan spektrofotometri serapan atom (SSA) didapatkan kadar sampel 1 sebesar 0,56\%, sampel 2 sebesar $0,28 \%$, dan sampel 3 sebesar $0,45 \%$. Pada penelitian ini diambil sampel urine dari mahasiswi tingkat tiga Prodi DIII Analis Kesehatan Pekanbaru. Berdasarkan survey awal yang dilakukan didapatkan bahwa rata-rata mahasiswi Analis Kesehatan menggunakan serum pemutih wajah tanpa mengetahui kandungan dari serum pemutih wajah tersebut.

\section{METODE}

Penelitian ini menggunakan metode analisa kualitatif. Desain penelitian adalah intervensional dan jenis penelitian adalah eksperimen. Sampel uji diambil berdasarkan kriteria yang sudah ditetapkan oleh peneliti yaitu, mahasiswi tingkat 3 A, B dan C Prodi DIII Analis Kesehatan yang menggunakan serum pemutih wajah sekurang-kurangnya 1 tahun, bersedia menjadi subjek penelitian dan dalam keadaan sehat.

Alat-alat yang digunakan dalam penelitian ini adalah bunsen, kaki tiga, tabung reaksi dan rak, pipet tetes, pipet volume, kertas saring, erlemeyer, bola hisap, kawat tembaga, kaca arloji, plat tetes, sarung tangan dan masker, pot penampung urine. Adapun bahan yang digunakan dalam penelitian ini adalah sampel urine, larutan campuran asam klorida $25 \%$ dan asam nitrat pekat (3:1), kalium iodida $0,5 \mathrm{~N}$, larutan campuran natrium sulfat-kalium iodida, larutan tembaga (II) sulfat $0,9 \mathrm{~N}$, Larutan stok $\mathrm{Hg} 1 \mathrm{mg} / \mathrm{mL}$, akuades.

\section{Prosedur Kerja}

\section{Perlakuan Sampel, Blanko dan Pembanding, Kontrol}

Sampel, blanko, pembanding dimasukkan ke dalam labu erlemeyer sebanyak $5 \mathrm{Ml}$, lalu ditambahkan $10 \mathrm{~mL}$ campuran $\mathrm{HCl} 25 \%$ dan $\mathrm{HNO}_{3}$ pekat kemudian dipanaskan selama 30 menit menggunakan bunsen, jika menggunakan waterbath 45 menit sampai urine jernih.Pada sisa penguapan, tambahkan $10 \mathrm{~mL}$ akuades lalu dididihkan sebentar, kemudian dinginkan dan saring lalu lakukan uji identifikasi.

\section{Identifikasi Merkuri (Hg)}

Ambil masing-masing $1 \mathrm{~mL}$ dari pembanding, blanko, sampel, kontrol kemudian dimasukkan ke dalam masing-masing tabung reaksi yang telah diberi label, lalu tambahkan 1 tetes larutan kalium iodida 0,5 $\mathrm{N}$ dengan perlahan-lahan melalui dinding tabung.Hasil Positif (+) menunjukkan terbentuknya endapan berwarna merah jingga. 
Kawat tembaga yang terlebih dahulu diamplas hingga mengkilap dicelupkan ke dalam masing-masing larutan uji pembanding, blanko, dan sampel selama beberapa saat.Hasil positif(+) menunjukkan terbentuknya lapisan berwarna abu-abu mengkilap pada kawat tembaga, dan lebih jelas terlihat jika kawat tembaga tersebut dipanaskan pada nyala api.

Ambil masing-masing 1 tetes dari larutan uji pembanding, blanko, dan sampel (dalam suasana asam klorida $1 \mathrm{~N}$ atau asam nitrat $1 \mathrm{~N}$ ), kemudian masukkan ke dalam plat tetes yang telah diberi label, lalu tambahkan masing-masing dengan 1 tetes larutan campuran Natrium Sulfat-Kalium Iodida dan 1 tetes larutan tembaga (II) sulfat, kemudian dihomogenkan.Hasil positif (+) menunjukkan terbentuknya warna merah atau jingga sesuai dari kadar merkuri.

\section{Jenis dan Cara Pengumpulan Data}

Jenis pengumpulan data dalam penelitian ini didapat dari penyebaran kuesioner danhasil pemeriksaan laboratorium.

\section{Analisis Data}

Analisis data dalam penelitian ini dilakukan secara deskriptif dan disajikan dalam bentuk tabel dan dibahas sesuai referensi yang ada.

\section{HASIL DAN PEMBAHASAN}

Setelah melakukan penelitian identifikasi merkuri didalam urine didapatkan hasil 1 positif dari 15 sampel, diperoleh hasil sampel yang positif mengandung merkuri dikarenakan pada saat pengujian menggunakan larutan kalium iodida terbentuk warna merah jingga, pengujian menggunakan kawat tembaga terbentuk warna abu-abu mengkilat, pengujian menggunakan larutan campuran natrium sulfat-kalium iodida terbentuk warna endapan merah jingga. Hasil ini dapat dilihat pada tabel 1 . 
Tabel 1. Hasil Pengujian Merkuri (Hg) Pada Urine

\begin{tabular}{|c|c|c|c|c|}
\hline \multicolumn{5}{|c|}{ Pemeriksaan } \\
\hline $\begin{array}{c}\text { Identifikasi } \\
\text { Sampel }\end{array}$ & $\begin{array}{l}\text { Uji Kalium } \\
\text { Iodida }\end{array}$ & $\begin{array}{l}\text { UjiKawat } \\
\text { Tembaga }\end{array}$ & $\begin{array}{c}\text { UjiCampuran } \\
\text { Natrium Sulfat- } \\
\text { KI Dan Tembaga } \\
\text { II Sulfat }\end{array}$ & Keterangan \\
\hline Pembanding & Merah jingga & Perak mengkilat & Merah jingga & Positif \\
\hline Blanko & Kuning jernih & Kuning & Kuning jernih & Negatif \\
\hline Kontrol & Merah jingga & Perak mengkilat & Merah jingga & Positif \\
\hline Sampel A & Merah jingga & Perak mengkilat & Merah jingga & Positif \\
\hline Sampel B & Kuning jernih & Kuning & Kuning jernih & Negatif \\
\hline Sampel C & Kuning jernih & Kuning & Kuning jernih & Negatif \\
\hline Sampel D & Kuning jernih & Kuning & Kuning jernih & Negatif \\
\hline Sampel E & Kuning jernih & Kuning & Kuning jernih & Negatif \\
\hline Sampel F & Kuning jernih & Kuning & Kuning jernih & Negatif \\
\hline Sampel G & Kuning jernih & Kuning & Kuning jernih & Negatif \\
\hline Sampel H & Kuning jernih & Kuning & Kuning jernih & Negatif \\
\hline Sampel I & Kuning jernih & Kuning & Kuning jernih & Negatif \\
\hline Sampel J & Kuning jernih & Kuning & Kuning jernih & Negatif \\
\hline Sampel K & Kuning jernih & Kuning & Kuning jernih & Negatif \\
\hline Sampel L & Kuning jernih & Kuning & Kuning jernih & Negatif \\
\hline Sampel M & Kuning jernih & Kuning & Kuning jernih & Negatif \\
\hline Sampel N & Kuning jernih & Kuning & Kuning jernih & Negatif \\
\hline Sampel O & Kuning jernih & Kuning & Kuning jernih & Negatif \\
\hline
\end{tabular}

Keterangan :

Positif $(+) \quad$ : Terbentuknya warna merah jingga (pada uji KI), terbentuknya warna abu-abu mengkilap (pada uji kawat tembaga) dan terbentuknya warna merah jingga (pada uji dengan larutan tembaga (II) sulfat)

Negatif (-) : Tetap warna kuning jernih (pada uji KI), tetap warna kuning (pada uji kawat tembaga) dan tetap warna kuning jernih (pada uji larutan tembaga (II) sulfat)

Kontrol : Urine + Larutan pembanding $\mathrm{Hg}+$ Reagen

Blanko : : Akuades + Reagen

Pembanding : Larutan pembanding $\mathrm{Hg}+$ Reagen

Identifikasi merkuri yang pertama dalam sampel dapat dilakukan menggunakan pereaksi KI 0,5 N yang sebelumnya sampel didestruksi dengan penambahan asam pekat. Sampel didestruksi dengan cara oksidasi senyawa organik dan hasil sampel yang sudah didestruksi atau filternya direaksikan dengan pereaksi KI 0,5 $\mathrm{N}$ yang memberikan warna merah jingga.

Dari 15 sampel yang diuji, didapat satu sampel yang positif mengandung merkuri yang ditandai dengan terbentuknya warna merah jingga pada saat diteteskan KI 0,5 $\mathrm{N}$ yaitu kode sampel A. Reaksi yang terjadi yaitu:

$$
\mathrm{Hg}_{2}^{2+}+21^{-} \rightarrow \mathrm{Hg}_{2} \mathrm{I}_{2} \text { endapan hijau merkurium (I) iodida }
$$


sedangkan sampel dengan kode B, C, D, E, F, G, H, I, J, K, L, M, N, dan O,pada saat diteteskan $\mathrm{KI}$ 0,5 $\mathrm{N}$ yaitu tidak mengalami perubahan warna ${ }^{[8]}$.

Identifikasi yang kedua yaitu dimasukkan ujung kawat tembaga yang telah diamplas kedalam larutan uji dan biarkan beberapa saat. Berdasarkan perbedaan potensial, dimana logam yang lebih tinggi potensialnya akan menempel yang membentuk lapisan pada kawat tembaga. Pada penelitian ini didapatkan hasil yaitu sampel dengan kode A terbentuk lapisan perak mengkilat pada kawat tembaga yang menyatakan sampel dengan kode A yang diidentifikasi positif mengandung merkuri pada sampel urine. Reaksi yang terjadi menurut ${ }^{[8]}$.

$$
\mathrm{Cu}+\mathrm{Hg}_{2}^{2+} \rightarrow \mathrm{Cu}^{2+}+2 \text { Hgendapan logam merkuri }
$$

Selanjutnya identifikasi ketiga yaitu dengan menggunakan larutan campuran natrium sulfat-kalium iodida sebanyak 1 tetes. Pada pengujian ditambahkan 1 tetes larutan uji kedalam plat tetes (dalam suasana asam klorida $1 \mathrm{~N}$ ), kemudian ditambahkan 1 tetes larutan tembaga II sulfat, pada larutan pembanding warna yang terbentuk merah jingga. Hasil yang didapatkan dari sampel kode A terbentuk warna endapan merah jingga yang menyatakan sampel positif mengandung merkuri.

Dari hasil penelitian yang dilakukan, sampel A positif mengandung merkuri. Merkuri merupakan kandungan yang kadang ditambahkan dalam kosmetik yang berfungsi mempercepat membuat kulit wajah putih dan bersih dalam waktu seminggu atau dua minggu. Melihat hasil pemakaian tersebut, banyak para wanita yang terus menggunakan kosmetik berbahan merkuri. Padahal merkuri sebenarnya tidak boleh digunakan oleh manusia, karena menurut ${ }^{[6]}$, merkuri termasuk dalam logam berat berbahaya, yang dalam konsentrasi kecil pun dapat bersifat racun. Hal tersebut terjadi karena senyawa merkuri akan mengalami kontak langsung dengan kulit sehingga mudah tereabsorbsi masuk kedalam darah dan mengakibatkan reaksi iritasi yang berlangsung cukup cepat diantaranya dapat membuat kulit terbakar, menjadi hitam, dan bahkan dapat membuat menjadi kanker kulit.

\section{SIMPULAN}

Hasil penelitian tentang identifikasi merkuri pada urine pengguna serum pemutih wajah dengan uji kualitatif terhadap 15 sampel yang dianalisa, terdapat 1 sampel yang positif mengandung merkuri yaitu didalam sampel A. Sedangkan sampel negatif yang tidak mengandung merkuri yaitu terdapat pada sampel B, C, D, E, F, G, H, I, J, K, L, M, N dan O. 


\section{UCAPAN TERIMA KASIH}

Ucapan terimakasih kepada pihak terkait yang telah membantu dan bekerjasama demi kelancaran penelitian ini.

\section{DAFTAR PUSTAKA}

1. Maharani, A. 2015. Penyakit Kulit, Perawatan, Pencegahan \& Pengobatan. Pustaka Baru Press. Yogyakarta.

2. Tranggono, R. dan Latifah, F. 2014. Kosmetologi. PT Gramedia Pustaka Utama. Jakarta

3. Darmono, 2009. Farmasi Forensik dan Toksikologi. UI-Press. Jakarta.

4. Soemirat. 2009. Toksikologi Lingkungan. Gadjah Mada University Press. Yogyakarta.

5. Asiah, N., Jazanul, A., Yahwardiah, S., dan Datten, B. 2015. Pengaruh Lama Kerja Terhadap Kadar Merkuri (Hg) Dalam Urin Pekerja Tambang Emas (Studi Kasus Di Desa Panton Luas Kecamatan Sawang Kabupaten Aceh Selatan). Jurnal pendidikan kimia. Volume 7 (2): Halaman 7-12.

6. Mona, R.K. Julius, P. Paulina, V.Y. 2018. Analisis Kandungan Merkuri (Hg) pada beberapa Krim Pemutih wajah tanpa Ijin BPOM yang beredar dipasar 45 Manado. Jurnal Ilmiah Farmasi. Volume 7(3): Halaman 12-26.

7. Armin, F, Zulharmita, Dinda, R.F. 2013. Identifikasi dan penetapan kadar merkuri (Hg) dalam krim pemutih kosmetika herbal menggunakan spektrofotometri serapan atom (SSA). Jurnal Sains dan Teknologi Farmasi. Volume 18 (1): Halaman 28-34.

8. Shevla, G. 1990. Buku Tekst Analisis Anorganik Kualitatif Makro dan Semimikro. Diterjemahkan Oleh Setiono, L., Pudjaatmaka, A., dan Handyana.. Kalman Media Pustaka. Jakarta. 